\title{
PENGARUH TINGKAT PENDIDIKAN MANAJER TERHADAP KINERJA PERUSAHAAN GO-PUBLIC
}

\author{
Moerdiyanto \\ FISE Universitas Negeri Yogyakarta (e-mail: murdiyanto_351@yahoo.com; \\ HP. 08164895080)
}

\begin{abstract}
The Effect of Managers' Educational Levels on the Go-Public Company Performance. This study aims to investigate the effect of managers' educational levels on the company performance. The population comprised all the manufacturing companies listed in the Indonesian Capital Market during the period of 2003-2007. The sample, consisting of 60 companies, was selected using the purposive sampling technique. The variable of managers' educational levels was controlled by the variables of accounting income and cash flows. The data on managers' educational levels were collected through a questionnaire and those on accounting income and the cash flows through documents from the company financial statement published in the Indonesian Capital Market. The data on the stock returns movement as a company's performance parameter were obtained from the Indonesian Securities Market Database (ISMD). The data were analyzed using the data panel regression, employing the software of EVIEWS-3 program. The result shows that the regression coefficient of managers' educational levels on the company performance is positive and statistically significant with $\alpha 1 \%$ and t-value at $\mathrm{p}<0.01$.
\end{abstract}

Keywords: managers' educational levels, accounting income, cash flow, gopublic company performance

\section{PENDAHULUAN}

Kinerja perusahaan adalah ukuran tingkat keberhasilan manajemen dalam mengelola sumberdaya keuangan perusahaan, terutama pada pengelolaan investasi sebagai upaya untuk menciptakan nilai bagi pemegang saham (Elizabeth, 2000: 76-85). Kinerja perusahaan tersebut merupakan hasil dari serangkaian proses bisnis dengan mengorbankan berbagai sumber daya, baik sumber daya manusia maupun keuangan perusahaan. Di pasar modal, para investor menilai tingkat kinerja saham perusahaan menggunakan parameter laba akuntansi dan arus kas. Untuk keadaan pasar modal Indonesia pertimbangan investasi masih banyak didasarkan pada informasi nonakuntansi (Parawiyati dan Baridwan, 1998: 2-3). Informasi nonakuntansi yang penting untuk mengukur kinerja saham perusahaan di antaranya adalah informasi tentang pendidikan manajer sebagai human capital yang dimiliki perusahaan. 
Manajer termasuk kategori human capital derajat tertinggi, yaitu intelectual capital yang paling sulit digantikan dan memiliki value added tinggi serta berperan sentral dalam mencapai kinerja saham perusahaan (Stewart, 1997:137). Banyaknya tantangan bisnis membawa implikasi bahwa hanya organisasi yang memiliki manajer dengan kemampuan tinggi yang bisa dengan cepat mengubah strategi menjadi tindakan, mengelola proses secara efisien, dan memaksimalkan sumbangan pekerja untuk menciptakan pertumbuhan perusahaan secara kontinyu (Ulrich, 1998:59-75).

Penelitian tentang hubungan pendidikan dengan kinerja perusahaan dilakukan oleh Ginn (2000:102-106) menemukan bahwa peningkatan kinerja organisasi ditentukan oleh pendidikan yang dimiliki seseorang. Pendidikan akan memenuhi apa yang secara khusus dibutuhkan untuk bisa berkinerja lebih baik sehingga memaksimalkan return on investment. Wright (1987:121-134) melakukan riset empiris terhadap kinerja manajer perusahaan-perusahaan konsultan di Amerika Serikat, menemukan bahwa manajer lulusan Master of Business Administration (MBA) mencapai prestasi kerja (kemajuan karir) yang lebih cepat dibanding lulusan Bachelor of Business Administration (BBA). Keunggulan komparatif MBA adalah keterampilan kepemimpinan dan kemampuan analisis pada tingkat manajer untuk dapat mengambil keputusan investasi yang menguntungkan. Keputusan-keputusan investasi yang menguntungkan akan mampu meningkatkan jumlah kas bersih yang dihasilkan dari usaha perusahaan.

Di Indonesia, penelitian Yunus (2000:143-156) menguji hubungan pendidikan dan pelatihan dengan produktivitas kerja karyawan industri di Jawa Timur. Dengan sampel sebanyak 5.475 orang ditemukan koefisien determinasi sebesar 0,657. Dengan analisis private rate of return, diperoleh nilai koefisien efisiensi eksternal pendidikan dan pelatihan sebesar $43,24 \%$, lebih besar dibanding pengalaman kerja yang hanya sebesar $11 \%$, sehingga pendidikan memiliki hubungan kuat dengan kinerja perusahaan. Oleh karena itu, tingkat pendidikan manajer merupakan faktor penting dalam pencapaian keberhasilan manajemen dalam mengelola investasi untuk menciptakan nilai bagi pemegang saham (Priharini, 2001:14-16).

Selain faktor-faktor non-keuangan tingkat pendidikan manajer tersebut, nilai bagi pemegang saham juga ditentukan oleh kinerja akuntansi, yaitu laba dan arus kas. Pentingnya informasi laba secara tegas telah disebutkan dalam Statement of Financial Accounting Concept (SFAC) No.1, bahwa selain untuk menilai kinerja perusahaan juga untuk membantu memperkirakan kemampuan laba yang representatif, serta untuk menaksir risiko investasi. Informasi laba merupakan informasi yang dibutuhkan para investor di pasar modal.

Ikatan Akuntan Indonesia (IAI) pada tanggal 7 September 1994 mengesahkan Pernyataan Standar Akuntansi Keuangan (PSAK) Nomor 2 
tentang Laporan Arus Kas. Tujuan pernyataan tersebut untuk memberikan informasi historis tentang perubahan kas dan setara kas suatu perusahaan selama suatu periode akuntansi melalui laporan arus kas. Arus kas tersebut diklasifikasi berdasarkan kegiatan operasi, investasi, dan pendanaan. IAI berpendapat bahwa informasi arus kas historis bermanfaat sebagai indikator dari arus kas masa depan, dan berguna untuk meneliti kecermatan taksiran arus kas masa depan yang telah dibuat sebelumnya.

Tujuan penelitian ini menguji hubungan pendidikan manajer dan kinerja saham perusahaan. Pada penelitian ini, pendidikan manajer dijadikan variabel independen terhadap kinerja perusahaan karena alasan berikut ini. Pertama, informasi tentang pendidikan manajer merupakan suatu keadaan khusus perusahaan karena secara kontekstual, dengan pendidikan yang memadai manajer akan mampu mengambil keputusan investasi yang produktif dan menguntungkan. Keputusan-keputusan investasi yang produktif dan menguntungkan dapat meningkatkan kinerja saham perusahaan. Hal ini sesuai dengan human capital theory yang menyatakan bahwa pendidikan merupakan investasi yang akan memberikan keuntungan melalui produktivitas kerja (Cohen, 1993:140-157). Produktivitas kerja bagi sumber daya manusia setingkat manajer perusahaan adalah keunggulannya dalam mengambil keputusan bisnis yang menempatkan prioritas utama pada kepentingan pelanggan, karyawan, dan pemegang sahamnya (Bowie, 1997:69-72). Wright (1987:121134) meneliti kinerja pimpinan perusahaan konsultan manajemen di Amerika Serikat menemukan bahwa pada semua tingkat, manajer bergelar MBA (Master of Business Administration) kinerjanya jauh lebih cepat dan lebih tinggi dibanding manajer bergelar BBA (Bachelor of Business Administration). Kedua, adanya pergeseran falsafah perusahaan tentang benchmark value creation (tolok ukur penciptaan nilai). Ukuran akuntansi tradisional semata seperti laba akuntansi dan arus kas dipandang kurang memadai sehingga diperlukan ukuran lain di antaranya yaitu tingkat pendidikan manajer yang keberadaannya tidak mudah dimanipulasi seperti halnya laba yang sering menjadi lahan rekayasa manajemen (Martin dan Petty, 2000:134-146).

Motivasi penelitian ini adalah sebagai berikut. Pertama, pada penelitian sebelumnya, kinerja perusahaan lebih banyak diprediksi dengan informasi keuangan yaitu laba akuntansi dan arus kas (Wilson, 1987; Baridwan, 1997; Asyik, 1998; Gultom, 1999; Sutopo, 2001; Board dan Day, 1989; Clubb, 1995 serta Hastuti dan Sudibyo,1998) tetapi hasilnya tidak selalu positif. Hal ini menunjukkan bahwa kesimpulan mengenai faktor-faktor yang mempengaruhi kinerja saham perusahaan belum konklusif. Penelitian ini mencari jawaban atas temuan yang belum konklusif tersebut dengan meneliti faktor nonkeuangan dalam memperkirakan kinerja saham perusahaan. Kedua, bahwa faktor 
pendidikan manajer sebagai informasi non-keuangan tentang intellectual capital yang sangat dibutuhkan untuk memaksimalkan kinerja saham perusahaan, belum dipertimbangkan pada penelitian-penelitian sebelumnya. Penelitian Donalson (1991:128139) menemukan beberapa faktor nonkeuangan, yaitu pendidikan manajer dan keterampilan karyawan perusahaan yang mempengaruhi perubahan harga saham.

Sumbangan yang diharapkan dari hasil penelitian ini adalah sebagai berikut. Pertama, memberikan bukti empiris bahwa pendidikan manajer merupakan salah satu prediktor terhadap kinerja saham perusahaan. Hasil penelitian ini diharapkan dapat digunakan sebagai bahan acuan dalam penelitian berikutnya tentang faktor-faktor yang mempengaruhi kinerja saham perusahaan. Kedua, hasil penelitian ini diharapkan dapat digunakan sebagai bahan pertimbangan oleh praktisi pasar modal, bahwa pengambilan keputusan investasi tidak hanya menggunakan pertimbangan laba akuntansi dan arus kas saja. Namun, pendidikan manajer sebagai informasi tentang intellectual capital yang secara khusus mampu meningkatkan kinerja yang lebih baik untuk memaksimalkan kinerja saham perusahaan di masa depan perlu dipertimbangkan.

Menurut human capital theory, pendidikan merupakan investasi yang akan memberikan keuntungan melalui produktivitas kerja (Cohen, 1993: 140-157). Human capital theory berasumsi bahwa nilai keuntungan in- vestasi pendidikan yang berupa perbedaan penghasilan merupakan aktualisasi diri dari nilai produktivitas marginal seseorang sebagai hasil dari perbedaan investasi human capital melalui pendidikan. Pengukuran terhadap nilai produktivitas marginal seseorang dapat dilakukan dengan earning function model, bahwa produktivitas adalah fungsi pendidikan sekolah, pendidikan keterampilan luar sekolah, pengalaman, dan motivasi kerja (Cohen, 1993:140-157). Becker dan Gerhart (1996:779-801) menyatakan bahwa peran pendidikan seseorang adalah sebagai pencipta nilai untuk keunggulan kompetitif melalui penurunan biaya, orientasi pada pelanggan, peningkatan produktivitas dan komitmen kerja.

Tingkat pendidikan personel dalam perusahaan disebut sebagai modal intelektual. Modal intelektual memiliki peranan yang sangat penting dan strategis di dalam perusahaan. Joesoef (2003:123) menyatakan bahwa ditinjau secara ekonomi, dengan modal intelektual memungkinkan manusia untuk meningkatkan produktivitasnya, memelihara dan mengembangkan sumber daya yang dimiliki serta membina motivasi yang tinggi dalam mencapai prestasi. Pennings, Lee, dan Witeloostuijn (1998:435-438) membedakan modal intelektual menjadi tiga: (1) human capital yaitu tingkat pendidikan dan kemampuan sumber daya manusia yang dimiliki perusahaan seperti manajer dan karyawan; (2) structural capital yaitu kemampuan perusahaan menyimpan, mempertahankan dan mengkonversi- 
kan pengetahuan spesialisasi sumber daya manusia yang dimiliki menjadi kinerja perusahaan; (3) customer capital yaitu pengetahuan yang dimiliki bersama di antara organisasi dan pelanggan karena terjalinnya knowledge sharing yang baik sehingga reputasi organisasi di mata pelanggan menjadi tinggi.

Vaizey (1992:36) yang melakukan penelitian di negara-negara maju menemukan bahwa pendidikan dilakukan untuk mengubah kinerja, bukan untuk memelihara nilai-nilai tradisi. Pendidikan dimanfaatkan pada nilai produktivitasnya sehingga pendidikan digunakan untuk memilah dan memilih tenaga kerja yang dianggap produktif dalam rangka meningkatkan kinerja organisasi. Hasil analisis riset mereka menemukan fakta bahwa pendidikan berpengaruh positif pada kinerja organisasi dan signifikan pada alfa $1 \%$. Di lingkungan industri dan bisnis, kreativitas seharusnya dimiliki oleh orang-orang tertentu seperti manajer, pengembang, dan perancang karena pada perusahaan-perusahaan modern yang serba otomatis, pimpinan dituntut kemampuan adaptasi secara kreatif untuk mampu memecahkan masalah dan menemukan gagasan-gagasan baru yang membawa kemajuan usaha (Vernon, 2002: 124). Manajer perusahaan merupakan unsur organisasi bisnis yang sangat menentukan lancar tidaknya organisasi dalam mewujudkan sasaran dan tujuannya. Menurut Arvan (2004:98), manajer adalah seseorang yang mencapai hasil melalui orang lain dengan jalan spesialisasi dalam pekerjaan, memimpin, merencanakan, menyusun, dan mengawasi. Manajer harus memiliki keahlian untuk menuntun dan membimbing orang lain. Manajer adalah orang yang mengatur pekerjaan dan kerjasama yang baik dengan menggerakkan orang untuk mencapai sasaran. Ia berwenang dan bertanggung jawab membuat rencana, mengatur organisasi, membimbing, dan mengarahkan orang serta mengawasi pelaksanaannya untuk mencapai sasaran dan tujuan tertentu.

Penelitian tentang pengaruh pendidikan manajer terhadap kinerja perusahaan telah dilakukan Wright (1987: 121-134) yang meneliti kinerja 110 manajer puncak perusahaan konsultan di Amerika Serikat yang terdiri dari 54 orang bergelar MBA dan 56 orang BA. Hasil penelitian menemukan bahwa manajer bergelar MBA mampu mencapai kinerja perusahaan yang lebih tinggi dibandingkan dengan yang bergelar BA, dengan perbedaan yang signifikan $(\mathrm{p}=0,04)$. Kelsey, et. all, (1983:80) yang menyatakan bahwa tingkat pendidikan mempengaruhi kinerja perusahaan. Du (2007:45) dalam penelitian survainya di Xi'an China menyatakan bahwa pendidikan berhubungan positif terhadap kinerja perusahaan dan secara statistik signifikan pada alfa $5 \%$. Sedangkan di Indonesia, Jalius (1991:112) telah meneliti faktor-faktor yang mempengaruhi kinerja organisasi. Dalam penelitiannya, dia menemukan bahwa tingkat pendidikan manajer berpengaruh signifikan terhadap kinerja organisasi. Pada perusahaan-perusahaan yang go-public, Sulaiman (1994:146) menguji 
informasi nonkeuangan yang mempengaruhi perubahan harga saham. Ia menemukan bahwa pendidikan manajer (sebagai faktor nonkeuangan) berpengaruh positif terhadap perubahan harga saham.

Selain faktor-faktor nonkeuangan tingkat pendidikan manajer tersebut, nilai bagi pemegang saham juga ditentukan oleh kinerja akuntansi yaitu laba dan arus kas. Pentingnya informasi laba secara tegas telah disebutkan dalam Statement of Financial Accounting Concept (SFAC) No.1, bahwa selain untuk menilai kinerja perusahaan juga untuk membantu memperkirakan kemampuan laba yang representatif, serta untuk memperkirakan resiko investasi. Informasi laba merupakan informasi yang dibutuhkan oleh para investor di pasar modal. Wilson (1987:302-306) yang menguji kandungan informasi laba akrual dan komponen dana. Studi ini menguji apakah kedua variabel tersebut memiliki tambahan informasi melebihi laba itu sendiri. Ia mengukur komponen laba akrual berdasarkan modal kerja dari operasi dikurangi laba. Sedangkan komponen dana diukur atas dasar modal kerja dari operasi. Studi ini membuktikan bahwa komponen laba akrual dan komponen dana memiliki tambahan informasi untuk penilaian kinerja perusahaan.

Selanjutnya, Baridwan (1997:12) meneliti manfaat laporan arus kas dengan menguji perbedaan distribusi variabel arus kas dan variabel laba. Supriyadi (1998:148) juga meneliti kemampuan arus kas dalam memprediksi arus kas di masa depan. Durya
(1999:13) menguji dengan membandingkan volume perdagangan dan return saham sebelum dan sesudah perusahaan menerbitkan laporan arus kas. Sutopo (2001:112-19) menguji kandungan informasi arus kas dibandingkan informasi laba.

Berdasarkan hasil-hasil uji empiris di atas menunjukkan adanya hubungan antara laba dan arus kas dengan kinerja perusahaan. Oleh karena itu, pada penelitian ini informasi laba dan arus kas menjadi variabel kontrol. Donalson (1991:131-137) menguji informasi nonkeuangan yang mempengaruhi perubahan harga saham. Penelitian mereka menemukan bahwa pendidikan manajer (sebagai faktor nonkeuangan) berpengaruh positif terhadap perubahan harga saham, dan signifikan pada alfa $5 \%$. Berdasar landasan berpikir tersebut, maka dihipotesiskan bahwa: "Pendidikan manajer, dikontrol dengan laba akuntansi dan arus kas, memiliki pengaruh positif terhadap kinerja saham perusahaan".

\section{METODE MODEL EMPIRIS}

Penelitian ini mengambil populasi pada 156 perusahaan manufaktur yang terdaftar di Bursa Efek Indonesia (BEI) Jakarta. Sampel penelitian ditetapkan dengan teknik purposive sampling dengan kriteria tertentu dan diperoleh sebanyak 60 perusahaan. Waktu penelitian adalah selama 5 tahun, yaitu tahun 2003 sampai dengan 2007. Responden penelitian adalah 60 orang manajer puncak dari perusahaan-perusahaan yang terpilih sebagai sampel penelitian. 
Model untuk menggambarkan pengaruh pendidikan manajer pada return saham dengan memasukkan laba dan arus kas sebagai variabel kontrol adalah seperti berikut ini.

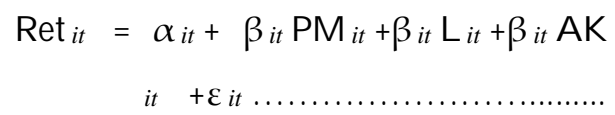

Hipotesis didukung jika $\beta_{i t} \mathrm{PM}_{i t}$ positif dan signifikan pada alfa $5 \%$.

\section{METODE ANALISIS}

\section{Pengujian Hipotesis}

Untuk menguji hipotesis penelitian ini digunakan model regresi data panel (Baltagi, 2003:168), seperti verikut.

$\operatorname{Ret}_{i t}=\beta_{0}+\beta_{1} \mathrm{PM}_{i, t}+\beta_{2} \mathrm{~L}_{i, t}+\beta_{3} \mathrm{AK}$

$$
i, t+\varepsilon_{i t}
$$

Keterangan:

$\operatorname{Ret}_{i, t}$ adalah variabel dependen: return saham i pada periode $t$.

$\mathrm{PM}_{i, t}$ adalah variabel independen: pendidikan manajer perusahaan i pada periode $t$

$\mathrm{L}_{i, t}$ adalah variabel kontrol: laba perusahaan i pada periode $t$

$\mathrm{AK}_{i, t}$ adalah variabel kontrol: arus kas perusahaan i pada periode $t$

$\beta_{0}=$ konstanta

$\beta_{1}, \beta_{2}, \beta_{3}=$ parameter estimasian

$\varepsilon_{i t}=$ disturbance error.

Analisis regresi data panel dilakukan dengan pendekatan random effect menggunakan software Eviews3, yaitu alat bantu software komputer ekonometrika untuk melakukan esti- masi regresi data panel yang memiliki tingkat presisi tinggi. Metode ini dipilih dengan pertimbangan bahwa sampel diambil berdasarkan purposive random sampling dari populasi perusahaan-perusahaan sejenis, yaitu kelompok industri manufaktur yang terdaftar di Bursa Efek Indonesia. Pada pendekatan random effect ini, variabel gangguan $\left(\mu_{i}\right)$ diasumsikan berbeda antar individu dari 60 perusahaan sampel, tetapi tetap antar waktu dalam periode 2003-2007.

\section{Pengujian Spesifikasi Model}

Pengujian spesifikasi model untuk pengujian hipotesis penelitian dilakukan dengan menggunakan tes Lagrange Multiplier atau LM-test (Gujarati, 1995:143). Teknik pengujian ini digunakan untuk sampel besar yang bersifat asimtotik dengan menggunakan distribusi chi squares. Langkah-langkah LM-test adalah berikut ini.

Mengestimasi regresi pada persamaan berikut untuk mendapatkan residuals $\mu_{i}$

$$
\begin{aligned}
& \operatorname{Ret}_{i t}=\alpha+\beta_{1} \mathrm{PM}_{i, t}+\beta_{2} \mathrm{~L}_{i, t}+\beta_{3} \\
& \mathrm{AK}_{i, t}+\mu_{i t}
\end{aligned}
$$

Meregres residuals yang dihasilkan pada langkah 1 pada pendidikan manajer (PM), laba (L), arus kas (AK) seperti berikut ini.

$\mu_{i t}=\alpha+\beta_{1} \mathrm{PM}_{i, t}+\beta_{2} \mathrm{~L}_{i, t}+\beta_{3}$

$\mathrm{AK}_{i, t}+\varepsilon$ it

Menghitung $\mathrm{n} \times \mathrm{R}^{2}$ atau chi-square value dari persamaan (3);

Menolak model (1), jika chi-square value yang dihasilkan dari langkah 
ketiga melebihi critical chi-square value pada level signifikansi yang ditentukan.

\section{HASIL DAN PEMBAHASAN HASIL PENGUJIAN HIPOTESIS}

Pengujian hipotesis dilakukan dengan analisis regresi model Regresi Data Panel melalui pendekatan Random Effect metode Generalized Least Squares (GLS). Pendekatan random effects juga disebut dengan Error Component Model (ECM) karena perbedaan intersep dan slope antarindividu dan antarwaktu dijelaskan oleh variabel gangguan (error). Dalam hal ini, variabel gangguan $\mu_{i}$ berbeda-beda antarindividu perusahaan, tetapi tetap antarwaktu. Perbedaan antarindividu perusahaan diakibatkan karakteristik masing-masing perusahaan berbeda satu dengan lainnya. Adapun asumsi ECM meliputi: (1) nilai harapan variabel gangguan sama dengan nol; (2) varian variabel gangguan homoskedastik; (3) variabel gangguan dari perusahaan yang sama dalam periode yang berbeda saling berkorelasi; dan (4) variabel gangguan dari perusahaan yang berbeda tidak berkorelasi (Anonim, 2007:179-188). Akibat adanya korelasi antarvariabel gangguan perusahaan yang sama dalam periode berbeda tersebut, metode ordinary least quare (OLS) tidak dapat digunakan untuk mendapatkan estimator yang efisien. Oleh karena itu, pada model random effect estimasi digunakan Generalized Least Squares (GLS).

Model pengujian hipotesis dengan persamaan (4) di atas yaitu:

$\operatorname{Ret}_{i t}=\beta_{0}+\beta_{1} \mathrm{PM}_{i, t}+\beta_{2} \mathrm{~L}_{i, t}+\beta_{3} \mathrm{AK}$

$$
i, t+\varepsilon_{i t} .
$$

Dengan bantuan software Eviews-3, diperoleh hasil seperti pada tabel berikut ini.

Tabel 1.Hasil Estimasi Regresi Data Panel dengan Pendekatan Random Effects

$\begin{array}{ll}\text { Dependent variable } & : \text { Kinerja saham yaitu return } \\ \text { Method } & : \text { Generalized Least Squares } \\ \text { Included observation } & : 5 \text { tahun } \\ \text { Number of cross-section used } & : 60 \text { perusahaan } \\ \text { Total panel observations } & : 300\end{array}$

\begin{tabular}{lcccc}
\hline \multicolumn{1}{c}{ Variable } & Coefficient & Std. error & t-statistic & Prob. \\
\hline C (constant) & 0.0034 & 0.0020 & $1.6656^{*}$ & 0,0469 \\
PM (Pend. Manajer) & $\mathbf{0 . 0 0 0 6}$ & 0.0002 & $3.6582^{* *}$ & 0.0003 \\
& \multicolumn{2}{c}{ Weighted } & Statistics \\
\hline R-squared & $\mathbf{0 . 0 8 5 0}$ & Mean dependent var. & 0.0156 \\
Adjusted R-squareed & 0.0757 & SD dependent var. & 0.0305 \\
S.E of regresion & 0.0293 & Sum squared resid & 0.2544 \\
F-statistic & $\mathbf{9 . 1 6 1 9 ^ { * * }}$ & Durbin-Watson stat & 2.0411 \\
Prob (F-statistic) & $\mathbf{0 . 0 0 0 0 0 8}$ & & \\
\hline
\end{tabular}

Keterangan: Variabel dependen: return saham

**, * secara statistik signifikan pada alfa $1 \%$ dan $5 \%$ 
Hipotesis penelitian ini menyatakan bahwa pendidikan manajer verpengaruh positif terhadap kinerja saham perusahaan. Hipotesis ini akan didukung jika $\beta_{i t} \mathrm{PM}_{i t}$ positif dan secara statistik signifikan pada alfa $5 \%$ (sig $t<0,05)$. Hasil analisis ditemukan koefisien regresi parsial dengan uji t sebesar 3.6582 menunjukkan bahwa terdapat hubungan positif pendidikan manajer dan kinerja saham perusahaan, dan secara statistik signifikan pada alfa $1 \%$ karena prob. ( $t$ statistic) 0,0003 lebih kecil dari 0,01. Hal ini sesuai dengan yang diharapkan pada hipotesis penelitian sehingga hipotesis penelitian terbukti. Maknanya, jika tingkat pendidikan manajer naik 1.00 satuan, nilai kinerja saham perusahaan tersebut akan naik sebesar 0.0006 satuan, pada keadaan faktor laba, arus kas dan faktor lainnya diasumsikan tetap.

Hasil regresi dengan uji F menunjukkan bahwa koefisien determinasi juga positif dan secara statistik signifikan pada alfa $1 \%$, prob. (t-statistic) 0,000 lebih kecil dari 0,010. Hal ini berarti model mampu menjelaskan variasi kinerja saham perusahaan sebesar $7,57 \%$.

Hasil regresi parsial dengan uji $t$ untuk variabel kontrol L (laba akuntansi) menunjukkan bahwa hubungan laba dan kinerja perusahaan positif dan secara statistik signifikan pada alfa 5\%, prob. ( $t$-statistic) 0.049 lebih kecil dari 0,050. Koefisien regresi yang signifikan ini menunjukkan bahwa laba akuntansi mempunyai pengaruh terhadap kinerja perusahaan. Selan- jutnya, hasil regresi parsial dengan uji t untuk variabel kontrol AK (arus kas) ditemukan adanya hubungan yang negatif dan secara statistik signifikan pada alfa 5\% karena prob. (t-statistic) 0.023 lebih kecil dari 0,050 . Temuan ini membuktikan bahwa arus kas memiliki pengaruh negatif terhadap kinerja saham perusahaan.

\section{PEMBAHASAN}

Secara teoretis, Joesoef (2003:56) menyatakan bahwa ditinjau secara ekonomis, pendidikan itu memungkinkan sumber daya manusia meningkatkan produktivitasnya, memelihara dan mengembangkan sumber daya yang dimiliki serta membina motivasi yang tinggi sehingga mampu meningkatkan kinerja perusahaan. Secara empiris, Cohen (1993:140-157) menguji human capital theory dengan mengkorelasikan pendidikan dan prestasi kerja, dan menemukan adanya hubungan positif dan signifikan pendidikan dengan prestasi kerja. Pengujian tentang human capital theory tersebut kemudian dikembangkan di berbagai bidang dan jenis organisasi baik organisasi bisnis maupun nonbisnis. Begitu juga, Jalius (1991:176) telah meneliti faktor-faktor yang mempengaruhi kinerja industri di Indonesia. Ia menemukan bahwa tingkat pendidikan manajer berpengaruh signifikan terhadap kinerja perusahaan.

Dalam pengujian hipotesis penelitian ditemukan bahwa pendidikan manajer mempunyai pengaruh yang positif dan signifikan pada alfa $1 \%$, yang berarti bahwa variasi kinerja saham (return) ditentukan oleh perubah- 
an pendidikan manajer. Pengaruh pendidikan manajer terhadap kinerja saham adalah kuat karena telah dikontroldengan variabel-variabel yang selama ini berpengaruh terhadap kinerja saham, yaitu laba akuntansi dan arus kas. Temuan ini mendukung penelitian Wright (1987:121-134) dalam penelitiannya dengan objek perusahaan-perusahan jasa di Amerika Serikat, yang menyimpulkan bahwa pendidikan manajer berpengaruh positif terhadap kinerja manajer perusahaan dan secara statistik, signifikan pada alfa $5 \%$. Hasil penelitian tersebut juga menemukan bahwa kinerja manajer yang berpendidikan MBA lebih tinggi dibandingkan manajer dengan tingkat pendidikan BBA. Hasil penelitian ini juga mendukung Kelsey, et all (1983: 78-85) yang menyatakan bahwa tingkat pendidikan mempengaruhi kinerja perusahaan. Du (2007:38-46) dalam penelitian survainya di Xi'an China menyatakan bahwa pendidikan berhubungan secara signifikan dengan kinerja perusahaan.

Pendidikan manajer menjadi prediktor terhadap kinerja perusahaan karena dengan tingkat pendidikan yang memadai maka manajer lebih matang, lebih tinggi ambisinya, lebih luas wawasan bisnisnya, mampu mengatasi masalah dengan lebih baik, memiliki keterampilan komunikasi lebih baik dan kemampuan memimpin yang lebih baik pula. Bermodal dengan kelebihan itulah manajer yang memiliki tingkat pendidikan tinggi mampu menganalisis kesempatan bisnis yang lebih prospektif menghasilkan keuntungan di masa depan. Ke- mampuan manajerial tersebut akhirnya direspon positif oleh pasar.

Temuan riset ini dapat memberikan inspirasi dan bukti empiris bahwa di era bisnis dengan persaingan yang ketat akibat kemajuan ilmu pengetahuan, teknologi, dan globalisasi ekonomi saat ini, maka human capital menjadi faktor ekonomi yang paling dominan untuk mencapai kinerja tertinggi dalam rangka memenangkan persaingan pasar. Pada era persaingan demikian, kreatifitas, inovasi manajer sebagai eksekutif pemegang otoritas operasi bisnis menjadi penentu kinerja perusahaan. Manajer yang memiliki pendidikan, pengetahuan, dan pengalaman paling handal yang mampu mengidentifikasi, menganalisis dan mengambil kebijakan bisnis yang tepat untuk meraih peluang optimum dalam rangka meraih keberhasilan (terutama kinerja finansial) di masa depan. Kinerja finansial tersebut dapat dilihat dari sisi internal perusahaan, yaitu tingkat rentabilitas dan jumlah aliran kas perusahaan. Kinerja dari sisi eksternal dilihat dari tingkat kesejahteraan pemegang saham, yaitu kinerja saham.

Satu hal penting bahwa riset ini menemukan bukti baru tentang pengaruh pendidikan manajer terhadap kinerja saham. Pengaruh pendidikan manajer adalah kuat karena telah dikontroldengan variabel-variabel yang selama ini berpengaruh terhadap kinerja saham. 


\section{KESIMPULAN}

Pendidikan manajer berpengaruh positif dan signifikan terhadap kinerja saham perusahaan, berarti pendidikan manajer merupakan informasi yang direaksi oleh investor dalam pengambilan keputusan investasi. Pendidikan manajer yang tinggi akan direaksi positif dan pendidikan manajer yang rendah akan direaksi negatif oleh pasar. Maknanya, jika tingkat pendidikan manajer naik atau turun sebesar 1 satuan, maka nilai kinerja saham perusahaan akan naik atau turun sebesar 0.0006 satuan, dengan faktor laba, arus kas dan faktor lainnya diasumsikan tetap. Jadi, secara empiris temuan ini menunjukkan bahwa hipotesis penelitian terbukti.

> Hasil regresi dengan uji F menunjukkan bahwa koefisien determinasi sebesaradjusted R-square 0,075693, positif dan secara statistik signifikan pada alfa 1\%, t-statistic) 0,000 lebih kecil dari 0,010. Temuan ini membuktikan bahwa model mampu menjelaskan variasi kinerja saham perusahaan sebesar 7,57\%.

Laba akuntansi dan arus kas perusahaan sebagai variabel kontrol terbukti juga memiliki hubungan yang signifikan dengan kinerja saham perusahaan.

\section{IMPLIKASI}

Berdasarkan hasil analisis data empiris, ditemukan bahwa tingkat pendidikan manajer, mempengaruhi kinerja saham perusahaan. Oleh karena itu, pendidikan manajer dapat digunakan sebagai informasi penting bagi para pelaku pasar untuk menilai kinerja saham perusahaan dengan mempertimbangkan laba akuntansi dan arus kas sebagai variabel kontrol. Implikasi praktis dari temuan ini, para investor dan calon investor di pasar modal perlu mempertimbangkan informasi tingkat pendidikan manajer yang tertera dalam laporan tambahan pada laporan keuangan perusahaan yang dipublikasikan di pasar modal untuk menentukan pilihan investasinya.

\section{SARAN}

Penelitian selanjutnya mengenai topik pendidikan manajer agar dilakukan ketika perekonomian di Indonesia dalam keadaan normal atau berkembang. Riset selanjutnya juga dapat dilakukan dengan memilah perusahaan dengan laba dan arus kas yang positif dan negatif, karena secara teoritis peranan tingkat pendidikan manajer dalam meningkatkan kinerja saham perusahaan dapat berbeda. Klasifikasi ini diharapkan dapat memberikan gambaran yang lebih lengkap mengenai perilaku manajer dalam mengelola perusahaan terkait dengan kemampuan mengambil keputusan investasi dan pendanaan dalam keadaan perusahaan berkembang (growth) dan keadaan perusahaan tidak berkembang (recovery).

Hasil penelitian ini membuktikan secara empiris bahwa pendidikan manajer memiliki hubungan yang kuat dengan kinerja saham. Oleh karena itu, dalam pengambilan keputusan investasi semestinya para 
investor dan calon investor mempertimbangkan informasi tentang tingkat pendidikan manajer perusahaan dalam melakukan prediksi terhadap kinerja saham perusahaan tersebut di masa yang akan datang. Dengan demikian, dalam pengambilan keputusan mengenai pemilihan portofolio optimal investasinya mereka perlu mempertimbangkan pendidikan manajer sebagai indikator penilaian kinerja saham yang akan dipilihnya.

\section{UCAPAN TERIMA KASIH}

Terima kasih kami ucapkan kepada pengurus Jurnal Cakrawala Pendidikan, terutama Dewan Redaksi yang telah memberi masukan terhadap artikel ini. Terima kasih juga diucapkan kepada semua staf yang terlibat pada penerbitan Jurnal Cakrawala Pendidikan ini.

\section{DAFTAR PUSTAKA}

Ambarworo, Hastuti, dan Sudibyo, Bambang, 1998. "Pengaruh Publikasi Laporan Arus Kas terhadap Volume Perdagangan Saham di Bursa Efek Jakarta". Jurnal Riset Akuntansi Indonesia. Vol. 1, No.2: 239-254.

Anomim, 1997. EVIEWS-3User's Guide: Estimation, Forcasting, Statistical Analysis, Graphics, Data Management and Simulation. California: The Quantitative Micro Software.
Arvan, Pradiansyah, 2004. You are A Leader. Jakarta: Elex Media Komputindo.

Asyik, Nurfajrih. 1998. “Kemampuan Rasio Keuangan dalam Memprediksi Return Saham". Jurnal Ekonomi dan Bisnis", Vol. 15, No. $3: 313-331$.

Baltagi, H.B, 2003. Econometric Analysis of Panel Data. New York: John Willey and Sons Publishing Co.

Baridwan, Zaki.1997. “Analisis Nilai Tambah Informasi Laporan Arus Kas". Jurnal Ekonomi dan Bisnis Indonesia". Vol.12 No.2: 114.

Becker, B. and Gerhard, B. 1996. "The Impac Resources Management on Organizational Performance: Progress and Prspect". Academyof Management Journal". 39 (4):779-801.

Board, JLG and JFS Day, 1989. "The Information Content of Cach Flow Figures". Accounting and Business Research (Winter): 3-11.

Bowie, Steve, 1997. "Mencari Model Manajer Terbaik (Terjemahan)". Majalah Ilmiah Manajemen. No. 114 (November-Desember), 6972.

Clubb, C.D.B., 1995. “An Empirical Study of the Information Content of Accounting Earnings, Fund Flows and Cash Flows in 
The UK". Journal of Business Financ and Accounting (January): 35-52.

Cohen, A.1993. “Organizational Commitment and Turnover: A Meta-Analysis". Academy of Management Journal", 36 : 140-157.

Donalson, S.,1991. “Beberapa Faktor Keuangan dan Nonkeuangan yang Mempengaruhi Harga Saham pada Pasar Modal Indonesia". Jurnal Ekonomi. Tahun XIII. No. 2, Agustus: 128-139.

$\mathrm{Du}, \mathrm{R}$, 2007. "Relationship Between Knowledge and Performance: A Survey in Xi'an China". Expert System with Applications. Vol. 32: 38-46.

Durya, Ngurah Panji Merta Agung, 1999. "Analisis Pengaruh Arus Kas, Modal Kerja, dan Laba Akuntansi terhadap Aktivitas Perdagangan Saham". Tesis. Program Pasacasarjana Universitas Negeri Yogyakarta.

Elizabeth, 2000. "Hubungan Laba Akuntansi dan Arus Kas terhadap Kinerja Perusahaan". Jurnal Riset Akuntansi Indonesia. Vol. 6, No. 2: 76-85.

Ginn, Charles, 2000. "Selecting the Right Aplicant". The Journal of Accountancy. November:102106.
Gujarati, Damodar N, 1995. Basic Econometrics, $3^{\text {th }}$ Ed. New York: McGraw-Hills, Inc.

Gultom, Charles Dickens. 1999. “Relevansi Nilai Arus Kas Operasi terhadap Unexpected Return di Bursa Efek Jakarta". Jurnal Bisnis dan Ekonomi. Vol. 1, No.2, Agustus: 77-95.

Jalius, Rasinov Chandra, 1991. "Kemampuan Penyesuaian Kerja pada Pekerja Sektor Informal". Disertasi. Tidak diterbitkan, PPS IKIP Jakarta.

Kelsey,R., Harvey D. dan Solomon. S. 1983. "An Accounting MBA: A Propost Alternative to The Traditional MBA and The Five Years Accounting Degree". Proceedings of the AAA Western Meeting. April, p 78-85.

Martin, John dan DJ.Wiliam Petty. 2000. Value Based Management: The Corporate Response to The Shareholder Revolution. Boston, Massachusett: Harvard Business School Press.

Parawiyati dan Baridwan,1998. "Kemampuan Laba dan Arus Kas dalam memprediksi Laba dan Arus Kas Perusahaan Go Public di Indonesia. "Jurnal Riset Akuntansi Indonesia" Vol.1, No. 1: 2-3.

Pennings, JM., Kyungmook Lee, dan AV, Witeloostuijn, 1998. “Hu- 
man Capital, Social Capital, and Firm Dissolution". Journal of Academy of Management. Vol. 41, No. 4: 425-440.

Priharini, Dian, 2001. "Pendidikan Manajer, Volume Transakasi Saham dan Kinerja Pasar Perusahaan". Jurnal Pendidikan Akuntansi Indonesia. Vol1, No.2. 14-16.

Soelaiman, Joesoef. 2003. Pendidikan Formal dan Pendidikan Nonformal di Indonesia. Surabaya: Penerbit Usaha Nasional.

Stewart, Thomas A. 1997. Reading in Management Accounting. New Jersey: Prentice Hall Publishing Co.

Sulaiman, S. 1994. "Analisis Beberapa Faktor yang Berpengaruh terhadap Harga dan Return Saham pada Perusahaan Food and Beverage yang Go-Public di Indonesia". Thesis. Program Pascasarjana Unair Surabaya.

Supriyadi, 1998. "The Association between Accounting Information and Future Cash Flows: An Indonesian Case Study". Dissertation. University of Kentucky.

Sutopo, Bambang. 2001. Dampak "Pemoderasi Perataan Laba ter- hadap Kandungan Informasi Inkremental Arus Kas". Disertasi. Yogyakarta: Universitas Gajah Mada.

Ulrich, D. 1998. "A New Mandate for Human Resources". Journal of Harvard Resource Planning. January-February.

Vaizey, J, 1992. "Pendidikan di Negara-negara Maju". (Terjemahan oleh Murtini, LP). Majalah Prisma, LP3ES No.2 Tahun X.

Vernon, P.E. 2002. Creativity. Middlesex: Penguin Book Inc.

Wilson, G.P.1987. "The Incremental Information Content of the Accrual and Funds Component of Earnings after Controlling for Earnings". Accounting Review. 62: 293-322.

Wright, Arnorld. 1987. The Comparative Performance of MBAs versus BAs in Public Accounting Firms Manager". Journal of Accountancy. June, 1987, p.121134.

Yunus, Muhamad. 2000. Hubungan Pendidikan dan Keterampilan terhadap Produktivitas Kerja Karyawan Industri di Jawa Timur". Tesis. Universitas Gajah Mada. 